\title{
Isolation and Characterization of Two Bacteriophages Infecting Kosakonia sacchari Bacterium Causing Potato Soft Rot Disease
}

\section{Abd Elhafeeez $E^{*}$, AlKhzindar M and Sayed ETA}

Faculty of Science, Department of Botany and Microbiology, Cairo University, 12613, Gamaa Street, Giza, Egypt

*Corresponding author: Abd Elhafeez E, Faculty of Science, Department of Botany and Microbiology, Cairo University, 12613, Gamaa Street, Giza, Egypt, Tel: 00201281233508; E-mail: eman.science@yahoo.com

Received date: July 05, 2018; Accepted date: August 30, 2018; Published date: September 20, 2018

Copyright: (C2018 Elhafeez EA, et al. This is an open-access article distributed under the terms of the Creative Commons Attribution License, which permits unrestricted use, distribution, and reproduction in any medium, provided the original author and source are credited.

\begin{abstract}
Potato crop is one of the most economically important crops, and is considered as the fourth main food crop in the world. One of the most important serious diseases of potato is bacterial soft rot disease. In our study, soil samples were collected from potato rhizosphere from a potato cultivated field in Giza, Egypt. Two bacteriophages were isolated on Kosakonia sacchari as a host, causing potato soft rot disease. Based on the genome characterization and electron microscopy, the two phages were named as vB_KsaM-C1 belonging to Myoviridae and vB KsaO-C2 belonging to Microviridae. Both phages sustained their activity more than 20 months with a remarkable decrease in phage titre. In addition both recorded the same TIP at $65^{\circ} \mathrm{C}$ and showed the optimum activity at $\mathrm{pH} 7$. The DEP of vB_KsaM-C1 was 10-7, while that of phage vB_KsaO-C2 was 10-9. A small scale application of the two isolated bacteriophages on infected potato tubers discs, in the lab, successfully inhibited bacterial soft rot caused by Kosakonia sacchari.
\end{abstract}

Keywords: Potato soft rot; Kosakonia sacchari; Rhizosphere; Myoviridae; Microviridae

\section{Introduction}

Potato soft rot is one of the most serious economic diseases, causing loss of approximately one billion dollars annually in potato worldwide $[1,2]$.

Enterobacteriaceae is a large family of Gram-negative bacteria comprising about twenty nine phytopathogenic bacteria as clarified by [3]. Enterobacteriaceae were familiarly known as enterobacteria or enteric bacteria. The main bacteria causing soft rot of potato are three coliforms: Pectobacterium atrosepticum (Pa), Pectobacterium carotovorum subsp. carotovorum (Pcc) and Dickeya sp. [1]. Enterobacter was considered as one of the largest genera of Enterobacteriace. Some species of genus Enterobacter were recently detected to be phytopathogens, causing many economic losses in plant crops; Soft rot disease was one of the recently detected diseases [4]. Novel proposed genera: Lelliottia gen. nov., Pluralibacter gen. nov and Kosakonia gen. nov. was reclassified and separated from genus Enterobacter [5]. Enterobacter cloacae were isolated from infected dragon fruit in Malaysia [6], decayed onion bulbs in USA [7] and rotted ginger rhizome in Brazil [8]. Lelliottia amnigena, a new Enterbacter species, was isolated from soft rotted onion bulbs in China [4].

Other bacteria causing potato soft rot are P. putida, $P$. tolaassii, $P$. aureofaciens and $P$. fluorescens which are symbian bacteria found in plant rhizosphere [9].

Bacteriophages are effective against antibiotic or heavy metalresistant bacteria, thus they can be used as antimicrobial alternative agents in plant protection $[9,10]$.

Bacteriophages are natural components of the biosphere and are nontoxic to the eukaryotic cell. They spread in the environment and are found where bacteria reside as in soil and sewage [10]. In contrast to the toxicity of antibiotics and heavy metals used in controlling soft rot disease, bacteriophage are host specific, that neither disturb the natural micro biota nor cause any infection problems to humans, animals or plants. Bacteriophages persist for long time in the environment thus can be used as an alternative instead of chemical or physical control for soft rot disease. In addition, they can be commercially formulated with a constant concentration and activity [11].

In recent years bacteriophages have been isolated, identified and proposed as bio control agents for bacterial diseases in plants. In order to control soft rot disease, bacteriophages belonging to Myoviridae were isolated from different sources [12] isolated bacteriophages from fertilizer solutions of green house, [13] isolated bacteriophages from soil samples of potato, [14] isolated PM1 bacteriophage from Chinese cabbage field and [11] isolated and characterized two novel broad host range lytic bacteriophages, ФPD10.3 and $\Phi P D 23.1$, from potato samples. Also, bacteriophages belonging to Podoviridae were isolated by [10] from soil samples, [15] isolated a novel lytic bacteriophage PPWS1 from an infected Japanese horseradish rhizome by soft rot, [16] isolated a novel bacteriophage vB_PcaP_PP2(PP2) to control soft rot disease caused by Pectobacterium carotovorum subsp. carotovorum. Other bacteriophages belonging to Siphoviridae were isolated by [12] from fertilizer solutions of green house and [17] from Caspian Sea water.

On the other hand, some limitations should be taken in consideration for phage therapy, as when phages are used to control phytopathogens they are associated with some factors as; the rapid destruction of phage by UV radiation surmounted by the application of phage in the evening, the location of susceptible bacteria, the moisture levels in the environment and on the leaf, the presence of chemicals which may compromise the viability of phage population [17]. 
The aim of our study was to isolate and characterize bacteriophages infecting bacteria causing potato soft rot disease to be used as bio control agents.

\section{Materials and Methods}

\section{Bacterial isolates and culture media}

Kosakonia sacchari was isolated in our lab from infected potato tubers with potato soft rot disease. The bacterial isolate sequence was deposited in the GeneBank, and given the accession number, KY235364 [18]. The bacterial isolate was cultured on nutrient agar (Each $1000 \mathrm{~mL}$ distilled water contained: $5 \mathrm{~g}$ peptone, $5 \mathrm{~g}$ sodium chloride, 1.5 beef extract, 1.5 yeast extract, $15 \mathrm{~g}$ agar) and incubated at $37^{\circ} \mathrm{C}$. Liquid culture was grown on nutrient broth (Each $1000 \mathrm{~mL}$ distilled water contained: $5 \mathrm{~g}$ peptone, $5 \mathrm{~g}$ sodium chloride, 1.5 beef extract, 1.5 yeast extract) at $37^{\circ} \mathrm{C}$ in a shaking incubator. The bacterial isolate was stored in $50 \%(\mathrm{v} / \mathrm{v})$ glycerol at $-20^{\circ} \mathrm{C}$.

\section{Bacteriophage isolation and enrichment}

Duplicates of three soil samples were collected at winter time $\left(15^{\circ} \mathrm{C}-20^{\circ} \mathrm{C}\right)$, in polyethylene bags from the soil surface, the rhizosphere and rhizoplane of potato tubers, from potato cultivated land, of pH 7.8, in Giza, Egypt. The soil samples were sieved to remove chunks, gravel and twigs. Phage enrichment was done according to [12] with some modifications. Triplicates of $5 \mathrm{~g}$ from each soil sample were added to $250 \mathrm{~mL}$ flasks containing $50 \mathrm{~mL}$ nutrient broth (supplemented by $0.02 \%$ magnesium chloride). The mixture was inoculated by $2 \mu \mathrm{L}$ of $24 \mathrm{~h}$ old culture of Kosakonia sacchari isolate and incubated on a horizontal shaking incubator at $37^{\circ} \mathrm{C}$ for $24 \mathrm{~h}$. One $\mathrm{mL}$ of chloroform was added to each flask and incubated on an orbital shaker for $30 \mathrm{~min}$ at room temperature. The suspension in each flask was centrifuged at $9700 \times \mathrm{g}$ for $10 \mathrm{~min}$ and the supernatant was decanted and filtered through nitrocellulose membrane bacterial filters $\left(0.22 \mathrm{~nm}\right.$ pore size). The enriched samples were stored in dark at $4^{\circ} \mathrm{C}$ until use. Bacteriophage isolation was done using double layer assay as described by [19].

\section{Bacteriophage purification and enumeration}

Each bacteriophage filtrate was serially tenfold diluted (10-1-10-10) using PBS, to be used in double layer assay. Bacteriophage purification and enumeration was done according to [12] with some modifications. The soft upper layer $[10 \mathrm{~mL}$ containing $8 \mathrm{~mL}$ soft nutrient agar supplemented by $0.2 \mathrm{~g} / \mathrm{L}$ magnesium chloride, $750 \mu \mathrm{L}$ of an overnight bacterial culture, $750 \mu \mathrm{L}$ bacteriophage filtrate and $500 \mu \mathrm{L}$ of $0.75 \%$ triphenyl tetrazolium chloride dye] was poured on bottom layer (15 $\mathrm{mL}$ )of nutrient agar media. All plates were incubated at $37^{\circ} \mathrm{C}$ and checked for plaque formation after $24 \mathrm{~h}$. After displaying plaques, single plaque was isolated using sterile pipette tips into a sterile eppendorf tube containing $1 \mathrm{~mL}$ sterile PBS. The eppendorf tube was vortexed and centrifuged at $11092 \times \mathrm{g}$ at $10^{\circ} \mathrm{C}$ for $15 \mathrm{~min}$ to remove bacterial cell debris as described by [20]. The supernatant was filtered through nitrocellulose bacterial filter $(0.2 \mathrm{~nm}$ pore size $)$. The obtained filtrate was tenfold serially diluted and the process of double layer assay was repeated several times to ensure obtaining pure single plaques of the isolated bacteriophage(s). The isolated purified bacteriophage(s) were stored in $\mathrm{PBS}$ at $4^{\circ} \mathrm{C}$ in dark.

\section{Transmission electron microscope (TEM)}

A drop of the phage suspension was adsorbed on a carbon coated copper grid, left to dry, then negatively stained by (3\%) uranyl acetate and examined under Transmission Electron Microscope (JEOL-JEM. 1010 TEM, Japan) and photographed at Regional Center for Mycology and Biotechnology, Azhar University, Cairo, Egypt.

\section{Extraction of phage nucleic acid}

In a clean sterile eppendorf, $500 \mu \mathrm{L}$ of concentrated phage lysate, 20 $\mu \mathrm{L}$ of $10 \%$ SDS and $1 \mu \mathrm{L}$ of $20 \mathrm{mg} / \mathrm{mL}$ proteinase $\mathrm{K}$ were added and incubated at $56^{\circ} \mathrm{C}$ for $1 \mathrm{~h}$. Equal volume of phenol was added and mixed. The mixture was centrifuged at $6050 \times \mathrm{g}$ for $5 \mathrm{~min}$ at room temperature. The supernatant was transferred to a fresh eppendorf tube and an equal volume of chloroform was added, inverted and spinned. The supernatant was transferred to a fresh tube, then two volumes of ice cold ethanol were added, mixed and kept overnight at $-20^{\circ} \mathrm{C}$. The mixture was spinned at maximum speed for $20 \mathrm{~min}$. The supernatant was discarded and $70 \%$ ethanol was added, spinned at maximum speed for $2 \mathrm{~min}$. The excess ethanol was removed by leaving the tube opened on bench for 15-30 min and the pellet was dissolved in $20 \mu \mathrm{L}$ TAE buffers [21]

\section{Detection of nucleic acid type}

Two eppendorf tubes containing $5 \mu \mathrm{L}$ of the extracted nucleic acid were tested to detect the type of nucleic acid of the phage. One tube was tested using $1 \mu \mathrm{L}$ of DNase and the other was tested using $1 \mu \mathrm{L}$ RNase. The mixtures were incubated at $37^{\circ} \mathrm{C}$ for $2 \mathrm{~h}$. The digested nucleic acid was electrophoresed using $0.8 \%$ agarose gel in $1 \mathrm{X}$ TAE buffer, stained with ethidium bromide $(0.5 \mu \mathrm{g} / \mathrm{mL})$. The extracted nucleic acid was visualized under a UV trans-illuminator $(\lambda=254 \mathrm{~nm})$ and photographed by digital camera (Canon) [21].

\section{Bacteriophage nomenclature}

The two isolated bacteriophages were named accordingly [22]. The nomenclature of bacteriophages was designed depending upon three main criteria preceded by vB (bacterial virus), followed by host bacteria abbreviation name, the viral family and a simple abbreviation of specific laboratory designation.

\section{Host range}

The host range of the isolated bacteriophages was determined using seven bacterial isolates. All these isolates cause soft rot disease. Two Gram negative isolates: Lelliottia amnigena and Enterobacter cloaca were isolated and identified in our lab [18]. Four Gram negative strains of Escherichia coli, Pectobacterium carotovorum subsp. carotovorum, Pseudomonas flourecens, Pseudomonas putida and the Gram positive strain of Bacillus pumilus were purchased from the Microbiological Resource Center (MIRCEN), Ain Shams University, Cairo, Egypt. Fresh overnight bacterial cultures were prepared. The isolated bacteriophages were used and plated with the bacteria under test using the double layer assay. The plates were incubated at $37^{\circ} \mathrm{C}$ and checked for plaque formation after $24 \mathrm{~h}$. 
Citation: Abd Elhafeez E, AlKhzindar M, Sayed ETA (2018) Isolation and Characterization of Two Bacteriophages Infecting Kosakonia sacchari Bacterium Causing Potato Soft Rot Disease. J Bacteriol Parasitol 9: 344. doi:10.4172/2155-9597.1000344

Page 3 of 7

\section{Physical Properties}

\section{Dilution end point}

Tenfold serial dilution (10-1-10-10) was prepared for each isolated bacteriophage. The double layer assay was done. The dilution end point was determined as last dilution of phage displayed clear plaques. This test was done in triplicates and repeated twice.

\section{Thermal inactivation point}

Thermal inactivation point was determined according to [23], with some modifications. Each isolated phage was subjected to different temperature conditions $\left(5^{\circ} \mathrm{C}, 15^{\circ} \mathrm{C}, 25^{\circ} \mathrm{C}, 35^{\circ} \mathrm{C}, 45^{\circ} \mathrm{C}, 55^{\circ} \mathrm{C}, 65^{\circ} \mathrm{C}\right)$ for 1 h. Double layer assay was done and the number of plaques was counted after $24 \mathrm{~h}$ to determine the temperature at which the isolated bacteriophage lost its activity. This test was done in triplicates and repeated twice.

\section{Effect of $\mathbf{p H}$}

Effect of $\mathrm{pH}$ on phage activity was done according to [23], with some modifications. Each isolated phage was incubated in buffer of different $\mathrm{pH}$ values $(1,2,3,4,5,6,7,8,9,10,11,12)$ at $5^{\circ} \mathrm{C}$ for $24 \mathrm{~h}$. Double layer assay was done and the number of plaques was counted after to determine the optimum $\mathrm{pH}$ for phage activity. This test was done in triplicates and repeated twice.

\section{Aging}

Aging effect of the isolated bacteriophages was done by testing phage infectivity using double layer assay by phage filtrates stored in dark at room temperature $\left(25^{\circ} \mathrm{C}-30^{\circ} \mathrm{C}\right)$ and in refrigerator at $5^{\circ} \mathrm{C}$, after $2,4,6,8,10,12,14,16,18$ months and up to 20 months. The number of plaques was calculated after $24 \mathrm{~h}$. This test was done in triplicates and repeated twice.

\section{Qualitative application of phage therapy in the lab}

The ability of the isolated bacteriophages to control potato soft rot by preventing rotting of potato slices was evaluated on small scale as described by [24] with slight modification. Concentrated phage lysate was prepared. Healthy potato tubers were selected from local markets, washed thoroughly by tap water, dried by tissue paper and surface sterilized by ethanol (70\%). The tuber was cut into slices $(0.5 \mathrm{~cm}$ thick) by sterile sharp blade and placed in sterilized petri plates $(12 \mathrm{~cm})$ containing wet Whattman no.1 filter papers. Small hole was done by a suitable sterile cork-borer at the center of each slice. Phage lysate ( $100 \%$ concentration) $(250 \mu \mathrm{L})$ was added to the hole at the center of the potato slice and left for $30 \mathrm{~min}$ before adding an equal volume of bacterial inoculum of $24 \mathrm{~h}$ old culture of Kosakonia sacchari suspended in PBS. Positive control was done by adding $250 \mu \mathrm{L}$ of the bacterial suspension plus $250 \mu \mathrm{L}$ of PBS to the hole. Negative control was done by adding $250 \mu \mathrm{L}$ of phage lysate plus $250 \mu \mathrm{L}$ of nutrient broth to the hole. All plates were incubated at $37^{\circ} \mathrm{C}$ for $(48 \mathrm{~h}-72 \mathrm{~h})$. The treated plates were compared by both the positive control plates and negative control ones to investigate the ability of the isolated bacteriophages in protecting potato slices from soft rotting. Duplicates of plates were done for each case and the experiment was repeated three times.

\section{Results}

\section{Bacteriophage isolation, purification and enumeration}

Two different bacteriophages were isolated. The two isolated phages were clearly different in plaque morphology and size as shown in Figure 1.

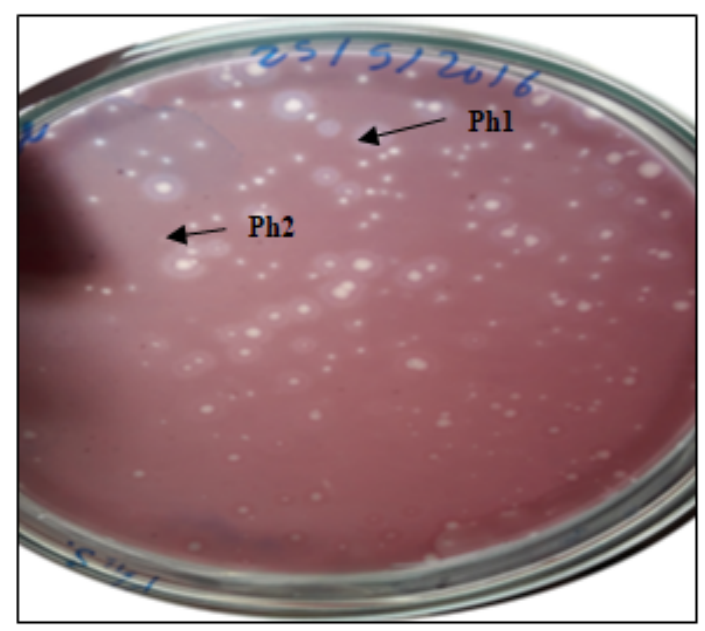

Figure 1: The plaques of the isolated bacteriophages infecting Kosakonia sacchari. The arrows show two different shaped plaques.

Two isolated bacteriophages were purified and designated as $\mathrm{Ph} 1$ which was characterized by halo zone like plaques of $(0.2 \mathrm{~cm})$ and $\mathrm{Ph} 2$ which was characterized by pin point like plaques as shown in Figure 2.
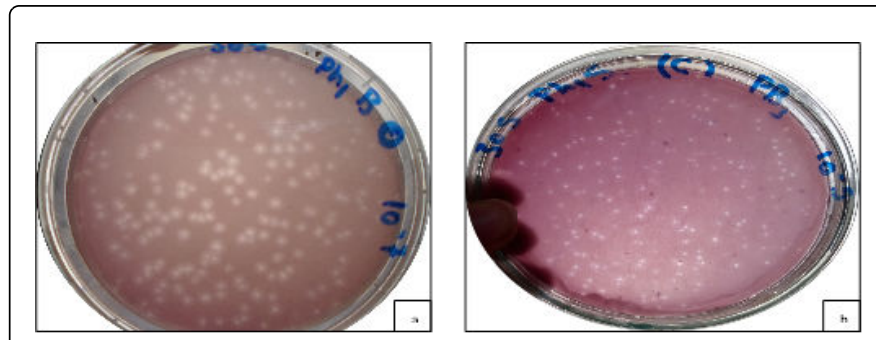

Figure 2: The shape of the purified bacteriophage Ph1 (a) and the shape of the purified bacteriophage $\mathrm{Ph} 2$ (b).

\section{Transmission electron microscope (TEM)}

The examination of bacteriophages negatively stained by $3 \%$ uranyl acetate under (TEM) showed that ph1 was characterized by icosahedral head of $58.04 \mathrm{~nm}$ diameter, short neck of $13.13 \mathrm{~nm}$ length and $8.06 \mathrm{~nm}$ width and long flexible tail of $96.42 \mathrm{~nm}$ length and 14.34 $\mathrm{nm}$ width. On the other hand examination of $\mathrm{Ph} 2$ showed that it was characterized by small polyhdral heads of $23.45 \mathrm{~nm}$ diameter as shown in Figure 3. 
Citation: Abd Elhafeez E, AlKhzindar M, Sayed ETA (2018) Isolation and Characterization of Two Bacteriophages Infecting Kosakonia sacchari Bacterium Causing Potato Soft Rot Disease. J Bacteriol Parasitol 9: 344. doi:10.4172/2155-9597.1000344

Page 4 of 7
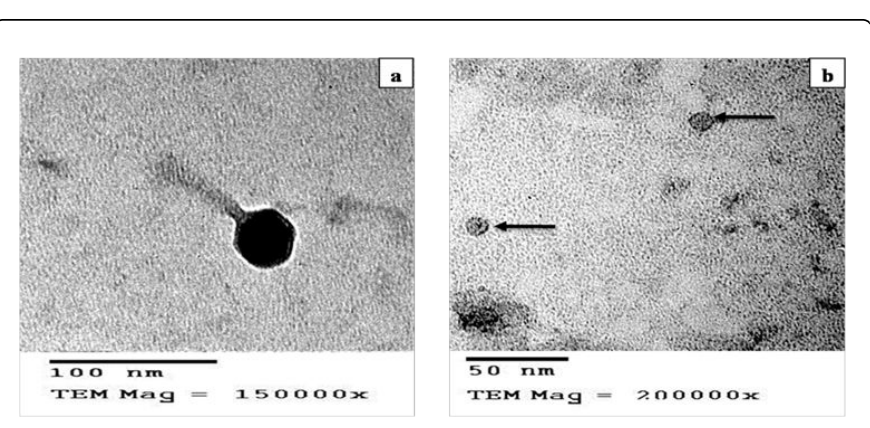

Figure 3: Transmission electron micrograph of $\mathrm{Ph} 1$ (a) and transmission electron micrograph of $\mathrm{Ph} 2(\mathrm{~b})$.

\section{Detection of nucleic acid}

Nucleic acid of both bacteriophages was determined using enzymatic digestion of DNase and RNase. Both phages nucleic acids weren't affected by RNase but they were digested by DNase as shown in Figure 4 for $\mathrm{Ph} 1$ and $\mathrm{Ph} 2$ respectively.
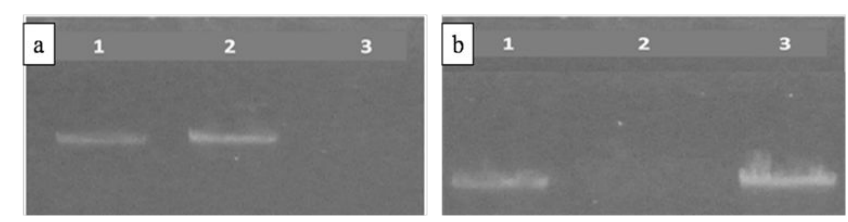

Figure 4: 0.8\% Agarose gel electrophoresis for Ph1 (a) nucleic acid: Total nucleic acid (lane 1) RNase digestion of genomic DNA (lane 2) and DNase digestion (lane 3). And for $\mathrm{Ph} 2$ (b) nucleic acid: Total nucleic acid (lane 1) DNase digestion of genomic DNA (Lane 2) and RNase digestion (Lane 3).

\section{Bacteriophage nomenclature}

Nomenclature of both bacteriophages was based upon the nucleic acid type and phage morphology under TEM. Both phages possess DNA genome but belonged to different families. Ph1 belonged to Myoviridae (M) and Ph2 belonged to Microviridae (O). Accordingly $\mathrm{Ph} 1$ was named vB_KsaM-C1 and ph2 was named vB_KsaO-C2.

\section{Host range}

Both isolated bacteriophages were found to be effective against Enterobacter cloaca isolate, Pectobacterium carotovorum subsp carotovorum and Pseudomonas flourecens. In addition, both isolated phages showed no lytic effect on Escherichia coli and Pseudomonas putida. Phage vB_KsaM-C1 showed lytic effect on Bacillus pumilus, however, it had no lytic effect on Lelliottia amnigena. On the other hand, phage vB_KsaO-C2 showed lytic effect on Lelliottia amnigena and showed no lytic effect on Bacillus pumilus. All these results are summarized in Table 1.

\begin{tabular}{|c|c|c|c|}
\hline The bacterial strain & Occurance & vB_KsaM-C1 & vB_KsaO-C2 \\
\hline Bacillus pumilus & Soil & $+v e$ & -ve \\
\hline Enterobacter cloaca isolate & $\begin{array}{l}\text { Soil, Plant } \\
\text { Human intestines }\end{array}$ & $+v e$ & $+v e$ \\
\hline Escherichia coli & $\begin{array}{l}\text { Fecal contaminated soil, } \\
\text { Intestines }\end{array}$ & -ve & $-v e$ \\
\hline Kosakonia sacchari & $\begin{array}{l}\text { Soil, } \\
\text { Sugarcane stem surface }\end{array}$ & $+v e$ & $+v e$ \\
\hline Lelliottia amnigena & Soil & -ve & $+v e$ \\
\hline Pectobacterium carotovorum subsp carotovorum & Plant & $+v e$ & $+\mathrm{ve}$ \\
\hline Pseudomonas flourecens & Soil, water & $+\mathrm{ve}$ & $+\mathrm{ve}$ \\
\hline Pseudomonas putida & Plant rhizosphere & -ve & -ve \\
\hline
\end{tabular}

Table 1: Host range of the two isolated phages against different bacterial strains causing soft rot disease. 
Citation: Abd Elhafeez E, AlKhzindar M, Sayed ETA (2018) Isolation and Characterization of Two Bacteriophages Infecting Kosakonia sacchari Bacterium Causing Potato Soft Rot Disease. J Bacteriol Parasitol 9: 344. doi:10.4172/2155-9597.1000344

Page 5 of 7

\section{Physical Properties}

\section{Dilution end point}

Dilution end point for phage vB_KsaM-C1 is 10-9. On the other hand, the dilution end point for phage $\mathrm{vB} \_\mathrm{KsaO}-\mathrm{C} 2$ is $10-7$. This was summarized in Table 2.

\begin{tabular}{|c|c|c|}
\hline \multirow[t]{2}{*}{ Sample dilution } & \multicolumn{2}{|c|}{ Number of plaques } \\
\hline & Vb_KsaM-Cl & Vb_KsaO-C2 \\
\hline $10^{-1}$ & Uncountable & Uncountable \\
\hline $10^{-2}$ & Uncountable & Uncountable \\
\hline $10^{-3}$ & Uncountable & Uncountable \\
\hline $10^{-4}$ & Uncountable & 674 \\
\hline $10^{-5}$ & Uncountable & 200 \\
\hline $10^{-6}$ & Uncountable & 17 \\
\hline $10^{-7}$ & 150 & 3 \\
\hline $10^{-8}$ & 45 & 0 \\
\hline $10^{-9}$ & 4 & 0 \\
\hline $10^{-10}$ & 0 & 0 \\
\hline
\end{tabular}

Table 2: Tenfold dilution assay of phage vB_KsaM-C1 and vB_KsaO-C2.

\section{Thermal inactivation point}

Studying the effects of different temperatures on vB_KsaM-C1 and vB_KsaO-C2 at different temperatures. The thermal inactivation point was determined for both phages at $65^{\circ} \mathrm{C}$ as shown in Figure 5 .
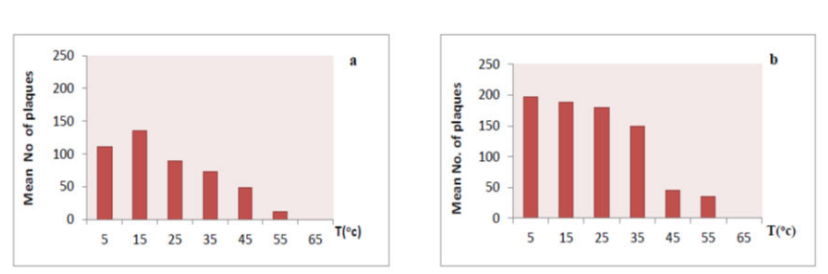

Figure 5: Thermal inactivation point was determined to be at $65^{\circ} \mathrm{C}$ for both bacteriophages; vB_KsaM-C1 (a) and vB_KsaO-C2 (b).

\section{Effect of $\mathrm{pH}$}

Optimum activity for phage $\mathrm{vB} \_\mathrm{KsaM}-\mathrm{C} 1$ was determined at $\mathrm{pH}$ (7-8), while phage infectivity decreased towards acidic and alkaline conditions. On the other hand, optimum activity for phage vB_KsaO$\mathrm{C} 2$ was determined at $\mathrm{pH} 7$, the infectivity decreased in high acidic and alkaline conditions. However, phage $\mathrm{vB} \_\mathrm{KsaO}-\mathrm{C} 2$ can tolerate the alkaline conditions up to $\mathrm{pH} 9$ as shown in Figure 6.

\section{Aging}

Both isolated bacteriophages sustained their lysis ability more than 20 months, either stored at room temperature $\left(25^{\circ} \mathrm{C}-35^{\circ} \mathrm{C}\right)$ or at refrigerator $\left(5^{\circ} \mathrm{C}\right)$. However, a significant decrease in phage infectivity expressed in a decrease in the plaque count by time was recorded as shown in Table 3.

\begin{tabular}{|l|l|l|l|l|}
\hline \multirow{2}{*}{ Time (Months) } & \multicolumn{3}{l}{ No of plaques } \\
\cline { 2 - 5 } & \multicolumn{2}{l|}{ vB_KsaM-C1 } & \multicolumn{2}{l|}{ vB_KsaO-C2 } \\
\cline { 2 - 5 } & $35^{\circ} \mathrm{C}$ & $5^{\circ} \mathrm{C}$ & $35^{\circ} \mathrm{C}$ & $5^{\circ} \mathrm{C}$ \\
\hline 0 & 150 & 150 & 200 & 200 \\
\hline 4 & 120 & 145 & 190 & 197 \\
\hline 8 & 100 & 133 & 152 & 188 \\
\hline 12 & 78 & 120 & 134 & 175 \\
\hline 16 & 55 & 100 & 100 & 158 \\
\hline 20 & 32 & 94 & 85 & 142 \\
\hline
\end{tabular}

Table 3: The effect of Aging on the isolated bacteriophages vB_KsaM$\mathrm{C} 1$ and $\mathrm{vB} \_\mathrm{KsaO}-\mathrm{C} 2$. 

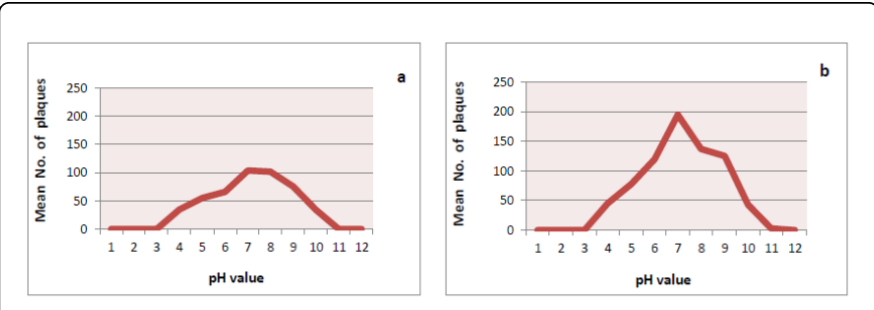

Figure 6: The effect of different $\mathrm{pH}$ values on phage vB_KsaM-C1 (a) and phage $\mathrm{vB}_{-} \mathrm{KsaO}-\mathrm{C} 2$ (b).

\section{Qualitative application of phage therapy in the lab}

Qualitative application of phage therapy in the lab using vB_KsaMC1: The isolated bacteriophage $\mathrm{vB} \_$KsaM-C1 successfully protected the potato slice from soft rot that should be caused by the inoculated host bacteria Kosakonia sacchari, compared by the infected one as shown in Figure 7.
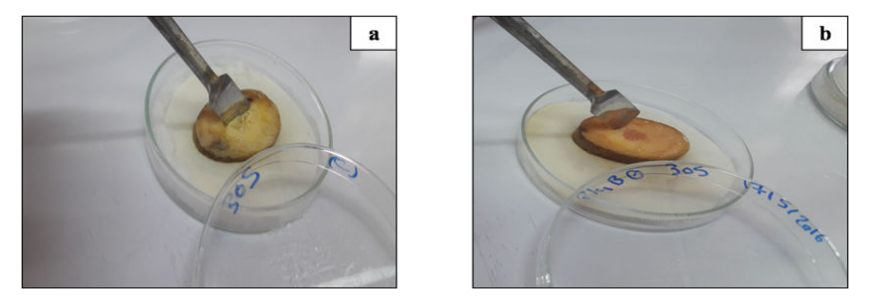

Figure 7: The infected potato slice by soft rot, showing macerated soft tissue (a), and the treated potato slice by phage vB_KsaM-C1, showing intact tissue (b).

Qualitative application of phage therapy in the lab using vB_EsaOC2: The isolated bacteriophage $\mathrm{vB} \_\mathrm{KsaO}-\mathrm{C} 2$ successfully protected the potato slice from soft rot that should be caused by the inoculated host bacteria Kosakonia sacchari, compared by the infected one as shown in Figure 8 .
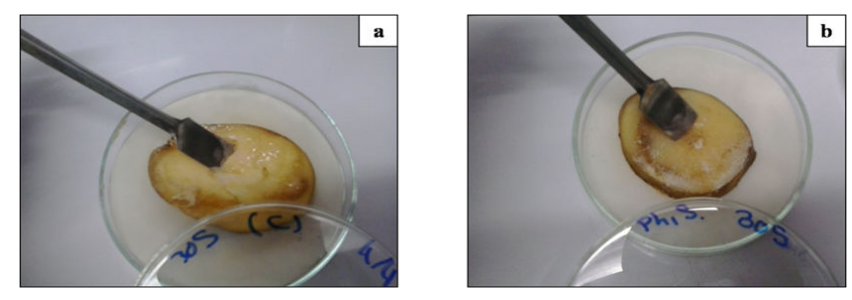

Figure 8: The infected potato slice by soft rot, showing macerated soft tissue (a), and the treated potato slice by phage vB_KsaO-C2, showing intact tissue (b).

\section{Discussion}

Potato soft rot is a serious economic disease, recorded to be caused by Enterobacteriacae [25]. Members of Enterobacter were recently detected to be phytopathgens causing soft rot [4].
Kosakonia sacchari is a novel genus, previously known as Enterobacter sacchari [5]. Kosakonia sacchari was isolated, identified and proved to cause potato soft rot [18]. On the other hand, Kosakonia sacchari was isolated as a nitrogen fixing bacteria that colonize sugar cane promoting its growth [26].

The present study aimed to isolate bacteriophages controlling bacteria which cause potato soft rot disease in Egypt. In an attempt to protect the great economic loss in potato crop either in the field or at storage. Two bacteriophages were isolated from potato tubers rhizosphere. The isolation and purification steps were done using double layer assay, to obtain clear visualized plaques, this was supported by [27], who suggested the improvement of phage diffusion rate using double layer plates.

According to [28], the phages were classified depending on phage morphology and genome type. Ph1 was related to Myoviridae, while, $\mathrm{Ph} 2$ was related to Microviridae.

Therefore, according to [22], Ph1 was named as vB_KsaM-C1 and $\mathrm{Ph} 2$ was named as vB_KsaO-C2.

In agreement to our results, previous studies reported the isolation of bacteriophages belonging to Myoviridae to control soft rot disease: [29] isolated a new species of temperate bacteriophage ZF40, [12] isolated bacteriophages from fertilizer solution samples, [3] isolated a novel flagellatropic bacteriophage $\Phi \mathrm{AT} 1,[30]$ isolated bacteriophages from 6 different soil samples cultivated by Chinese cabbage in Korea, [24] isolated nine bacteriopages from soil samples collected in Poland, [14] isolated PM1 bacteriophage from Chinese cabbage field, [11] isolated and characterized two novel broad host range lytic bacteriophages, ФPD10.3 and ФPD23.1, from potato samples collected from two different potato fields in central Poland, [17] isolated bacteriophages, from Caspian sea water and [16] isolated bacteriophages from potato tubers rhizospheres. On the other hand, bacteriophages belonging to Microviridae were reported to infect Enterobacteriacae members [31].

The two isolated phages were found to be thermo labile phages, as both showed thermal stability up to $55^{\circ} \mathrm{C}$.

Phage vB_KsaM-C1 showed optimum activity at $15^{\circ} \mathrm{C}$, with a noticeable decrease in plaque count at temperature degrees greater or less than $15^{\circ} \mathrm{C}$. In agreement to our results, [24] isolated bacteriophages belonging to Myoviridae showing maximum stability at temperature ranging from $4^{\circ} \mathrm{C}$ to $37^{\circ} \mathrm{C}$ with decreasing infectivity by increasing temperature.

On the other hand, phage vB_KsaO-C2 showed optimum activity at $5^{\circ} \mathrm{C}$, with a noticeable decrease in phage plaque count at temperature greater than $35^{\circ} \mathrm{C}$.

In our study, both bacteriophages sustained their optimum activity at neutral $\mathrm{pH}$ values, with a decrease in plaque count at acidic or alkaline conditions and total inhibition of phages infectivity at acidic (less than $\mathrm{pH} 4$ ) and alkaline (more than $\mathrm{pH} 10$ ) values. Our results are in agreement with [32] who stated that the phage optimum activity should be at neutral $\mathrm{pH}$ values. This is attributed to the adsorption of the phage on the host bacterial cell which is affected by $\mathrm{pH}$ value, due to charge alteration of protein capsid [33].

Bacteriophages infectivity is affected by temperature and $\mathrm{pH}$, as those factors cause lipid dissolving, DNA and protein denaturation, leading to phage structure damage [33]. 
Studying the longevity in vitro showed that both isolated bacteriophages sustained their lytic activity more than 20 months, either stored at room temperature $\left(25^{\circ} \mathrm{C}-35^{\circ} \mathrm{C}\right)$ or at refrigerator $\left(5^{\circ} \mathrm{C}\right)$, but with a significant decrease in phage titre. Our results are in agreement with [34] who proved the ability of the two phages T4 and C16 belonging to Myoviridae to sustain long-term storage up to years.

In our study, we succeeded to isolate two bacteriophages, vB_KsaM$\mathrm{C} 1$ and $\mathrm{vB} \_\mathrm{KsaO}-\mathrm{C} 2$ belonging to Myoviridae and Microviridae respectively, to control potato soft rot disease caused by Enterobacteriacea members.

Application of phage therapy on small scale supported their role in controlling soft rot disease, by protecting potato slices from rotting symptoms caused by the bacterial inoculum in non-protected potato slices.

Further studies concerning application of phage therapy on large scale to control soft rot disease in field, will be taken in consideration. However, the application of phage therapy in soil, will fate the disadvantage of phage inactivation by temperature and UV radiation of sunlight, which propose its use directly on potato tubers before planting or at storage [24].

\section{Declaration}

We declare that, our work has no conflict of interests.

\section{References}

1. Perombelon MCM (2002) Potato diseases caused by soft rot erwinias: An overview of pathogenesis. Plant Pathol 51: 1-12.

2. Chung YS, Goeser NJ, Cai X (2013) The effect of long term storage on bacterial soft rot resistance in potato. Am J Potato Res 90: 351-56.

3. Roux S, Krupovic M, Poulet A, Debroas D, Enault F (2012) Evolution and diversity of the Microviridae viral family through a collection of 81 new complete genomes assembled from virome reads. PLos One 7: e40418.

4. Liu S, Tang Y, Wang D, Lin N, Zhou J (2016) Identification and characterization of a new Enterobacter onion bulb decay caused by Lelliottia amnigena in China. Appl Microbiol 2: 1000114.

5. Brady C, Cleenwerck I, Venter S, Coutinho T, Vos PD (2013) Taxonomic evaluation of the genus Enterobacter based on multilocus sequence analysis (MLSA). Syst Appl Microbiol 36: 309-319.

6. Masyahit M, Sijam K, Awang Y, Ghazali M (2009) First report on bacterial soft rot disease on dragon Fruit (Hylocereus spp.) caused by Enterobacter cloacae in peninsular Malaysia. Int J Agric Biol 11: 659-666.

7. Schroeder B K, du Toit L J (2010) Effects of postharvest onion curing parameters on Enterobacter bulb decay in storage. Plant Dis 94: $1425-1430$.

8. Moreira SI, Dutra DC, Rodrigues AC, Oliveira JR, Dhingra OD, et al. (2013) Fungi and bacteria associated with post-harvest rot of ginger rhizomes in Espirito Santo, Brazil. Trop Plant Pathol 38: 218-226.

9. Soleimani Delfan A, Etemadifar Z, Bouzari M, Emtiazi G (2012) Screening of novel bacteriophage infection in Pseudomonas putida isolated from potato disease. Jundishapur J Microbiol 5: 550-554.

10. Lim J-A, Jee S, Lee D H, Roh E, Jung K, et al. (2013) Biocontrol of Pectobacterium carotovorum subsp. carotovorum using bacteriophage PP1. J Microbiol Biotechnol 23: 1147-1153.

11. Czajkowski R (2015) Bacteriophages of soft rot enterobacteriaceae-a mini-review. FEMS Microbiology Letters 363: 1-23.

12. Ravensdale M, Blom TJ, Gracia-Graza JA, Svircev AM, Smith RJ (2007) Bacteriophages and the control of Erwinia carotovora subsp. carotovora. Can J Plant Pathol 29: 121-130.
13. Adriaenssens EM, Van Vaerenbergh J, Vandenheuvel D, Dunon V, Ceyssens PJ, et al. (2012) T4-related bacteriophage LIME stones isolates for the control of soft rot on potato caused by 'Dickeya solani'. PLoS One 7: e33227.

14. Lim JA, Shin H, Lee DH, Han SW, Lee JH, et al. (2014) Complete genome sequence of the Pectobacterium carotovorum subsp. carotovorum virulent bacteriophage PM1. Arch Virol 159: 2185- 2187.

15. Hirata H, Kashihara M, Horiike T, Suzuki T, Dohra H, et al. (2016) Genome sequence of Pectobacterium carotovorum phage PPWS1, isolated from Japanese horseradish [Eutrema japonicum (Miq.) Koidz] showing soft-rot symptoms. Genome Announc 4: e01625-15.

16. Lee J, Kim S, Park TH (2017) Diversity of bacteriophages infecting Pectobacterium from potato fields. J Plant Pathol 99: 453-460.

17. Delfan AS, Etemadifar Z, Emtiazi G, Bouzari M (2015) Isolation of Dickeya dadantii strains from potato disease and biocontrol by their bacteriophages. Braz J Microbiol 46: 791-797.

18. Abd-Elhafeez E, AlKhazindar M, Sayed ETA (2018) Isolation and characterization of Enterobacter strains causing potato soft rot disease in Egypt. Minia Science Bulletin 29:1-13.

19. Łos' JM, Golec P, Wegrzyn G, Wegrzyn A, Łos' M (2008) Simple method for plating escherichia coli bacteriophages forming very small plaques or no plaques under standard conditions. Appl Environ Microbiol 74: 5113-5120.

20. Tovkach FI, Zhuminska GI, Kushkina AI (2012) Long term preservation of unstable bacteriophages of enterobacteria. Microbiol Z 74: 60-66.

21. Al Khazindar M, Sayed ETA, Khalil MS, Zahran D (2016) Isolation and characterization of two phages infecting Streptomyces scabies. Res J Pharm Biol Chem Sci 7:1-13.

22. Kropinski AM, Prangishvili D, Lavigne R (2009) The creation of a rational scheme for the nomenclature of viruses of Bacteria and Archaea. Environ Microbiol 11: 2775-2777.

23. Holmes DH (1956) The effect of various physical and chemical agents on Staphylococcus bacteriophage. Butler University Botanical Studies 13: 49-65.

24. Czajkowski R, Ozymko Z, Lojkowska E (2013) Isolation and characterization of novel soil borne lytic bacteriophages infecting Dickeya spp. biovar 3 ('D. solani'). Plant Pathol 63: 758-772.

25. Czajkowski R, Perombelon MCM, van Veen JA, van der Wolf JM (2011) Control of blackleg and tuber soft rot of potato caused by Pectobacterium and Dickeya species: A review. Plant Pathol 60: 999-1013.

26. Chen M, Zhu B, Lin L, Yang L, Li Y, et al. (2014) Complete genome sequence of Kosakonia sacchari type strain SP1. Stand Genomic Sci 9: 1311-1318.

27. Lillehaug D (1997) An improved plaque assay for poor plaque producing temperate lactococcal bacteriophages. J Appl Microbiol 83: 85-90.

28. Ackermann HW (2007) 5500 Phages examined in the electron microscope. Arch Virol 152: 227-243.

29. Tovkach FI (2002) Temperate bacteriophage ZF40 of Erwinia carotovora: Phage particle structure and DNA restriction analysis. Microbiol 71: 75-81.

30. Jee S, Malhotra S, Roh E, Jung K, Lee D, et al. (2012) Isolation of bacteriophages which can infect Pectobacterium carotovorum subsp. carotovorum. Res Plant Dis 18: 225-230.

31. Fane BA, Brentlinger KL, Burch AD, Chen M, Hafenstein S, et al. (2011) The Microviridae. In: The bacteriophages. Oxford Press J pp. 129-145.

32. Krasowska A, Biegalska A, Augustyniak D, Richert MM, Aukaszewicz M (2015) Isolation and characterization of phages infecting Bacillus subtilis. BioMed Res Internat 1: 1-10.

33. Wunsche L (1989) Importance of bacteriophages in fermentation processes. Acta Biotechnol 9: 395-419.

34. Ackermann HW (2004) Long-term bacteriophage preservation. WFCC Newsletter 38: 35-40. 